Int. J. Dev. Biol. 51: 495-506 (2007)

doi: $10.1387 /$ ijdb.072345ss

\title{
Hindbrain signals in otic regionalization: walk on the wild side
}

\author{
SYLVIE SCHNEIDER-MAUNOURY ${ }^{1,2}$ and CRISTINA PUJADES $*, 3,4$ \\ ${ }^{1}$ Laboratory of Developmental Biology, CNRS, ${ }^{2}$ Université Pierre et Marie Curie, Paris, France, \\ ${ }^{3}$ Developmental Biology Group, Departament de Ciències Experimentals i de la Salut, Universitat Pompeu Fabra and \\ ${ }^{4}$ Parc de Recerca Biomèdica de Barcelona PRBB, Barcelona, Spain
}

\begin{abstract}
The inner ear, the sensory organ responsible for hearing and balance, contains specialized sensory and non-sensory epithelia arranged in a highly complex three-dimensional structure. To achieve this level of complexity, a tight coordination between morphogenesis and cell fate specification is essential during otic development. Tissues surrounding the otic primordium and more particularly the adjacent segmented hindbrain, have been implicated in conferring signals required for inner ear development. In this review, we present the current view on the role of hindbrain signals in axial specification of the inner ear. The functional analysis of mutants of hindbrain segmentation genes, as well as the investigation of signaling pathways potentially involved, all point to an essential role of FGF, Wnt and Hh signaling in otic regionalization. However, these data provide conflicting evidence regarding the involvement of hindbrain signals in otic regionalization in fish and in amniotes. We discuss the possible origin of these differences.
\end{abstract}

KEY WORDS: hindbrain, patterning, otic regionalization, FGF signaling

\section{Basic structure of the adult inner ear}

The vertebrate inner ear is a sensory organ responsible for the senses of hearing, balance and detection of acceleration. It consists of a closed epithelial structure, the membranous labyrinth, composed of several sensory and non-sensory structures and surrounded by a bony capsule. The mechanosensory function of the inner ear is provided by the hair cells, which, along with supporting and secretory cells, are contained in the sensory epithelia. Hair cells are innervated by sensory neurons of the vestibular and acoustic ganglia that project to the vestibular and auditory nuclei in the brainstem.

The membranous labyrinth is subdivided into vestibular and auditory regions. The vestibule forms the dorsal part of the labyrinth and is responsible for the senses of motion and position. It comprises the three cristae, the sensory organs located at the basis of three orthogonally arranged semi-circular canals and the utricle and saccule, which contain two additional sensory organs, the maculae. The ventral auditory part is more diverse. In mammals it is composed of the cochlea, a coiled structure whose sensory epithelium is called the organ of Corti. In birds, the auditory region is composed of the basilar papilla, while in fish the saccule and lagena are both involved in hearing (Figure 1). In jawed vertebrates, the adult inner ear is highly regionalised along its three axes. In addition to the dorso-ventral (DV) subdivision into vestibular and auditory regions, an asymmetry along the medio-lateral (ML) axis is also obvious with, for instance, the endolymphatic sac and duct located in the medial part, close to the brain. The whole structure also shows pronounced anteroposterior (AP) asymmetry (Figure 1).

How are these asymmetries established during ear development? What are the signals involved in establishing these asymmetries and where do they come from? Are there similarities and differences in the mechanisms of otic patterning in the different model organisms analysed so far? In the present review we attempt to answer these questions, focusing on the role of the adjacent hindbrain, a highly patterned region of the embryonic brain whose function in otic development has been extensively studied. Although the first observations of the importance of the hindbrain in the development of the inner ear were done by experimental embryologists back in the 1940s, we will focus on the functional data obtained in mice, chick and zebrafish during the last 10 years. Thus, we only describe ear structure and development in these three vertebrate species and we do not discuss evolutionary aspects of ear patterning. For a comprehensive review on ear evolution, see Fritzch, this issue.

Abbreviations used in this paper: AP, antero-posterior; DV, dorso-ventral; FGF, fibroblast growth factor; ML, medio-lateral; ngn, neurogenin.

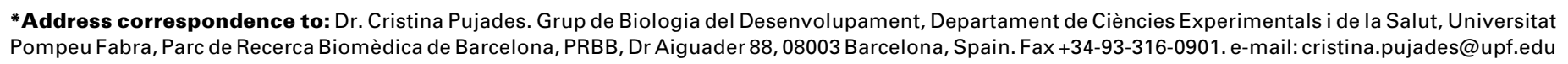




\section{Early stages of otic development}

The inner ear arises from the otic placode, an ectodermal thickening that forms lateral to the hindbrain during neurulation. At this stage, the hindbrain is subdivided into segments termed rhombomeres (see below). The placode is first visible morphologically at early somite stages, but long before, it is already prefigured by molecular markers, such as transcription factors of the Pax, Eya and DIx families (Riley and Phillips, 2003). The placode forms lateral to the caudal hindbrain and covers the length of about two rhombomeres (Figure 2). In chick, the otic placode is initially adjacent to $\mathrm{r} 4$ and $\mathrm{r} 5$ (Figure $2 \mathrm{Aa}$ ) and then at the otic cup stage is juxtaposed to $r 5$ and $r 6$. In fish, the placode is centred on $r 5$ and overlaps with both $r 4$ and $r 6$ (Haddon and Lewis, 1996) (Figure 2Ba). Then the placode transforms into the otic vesicle or otocyst, a morphogenetic process that varies among species. In amniotes and amphibians, the placode invaginates, forming the otic cup (Figure $2 \mathrm{Ab}$ ); then the cup closes and pinches off from the ectoderm to form the otic vesicle (Figure 2Acd). In fish (Haddon and Lewis, 1996) and reptiles (see review Barald and Kelley, 2004), the placode first individualises from the ectoderm (Figure 2Ba) and then cavitates (Figure 2Bb-d). Therefore, the intimate relationship between the otic vesicle and the hindbrain differs along the DV axis between amniotes and zebrafish.

The otocyst is a self-contained organ which gives rise not only to sensory and non sensory epithelia, but also to neurons of the statoacoustic ganglion (SAG, VIIlth ganglion, also called cochle-

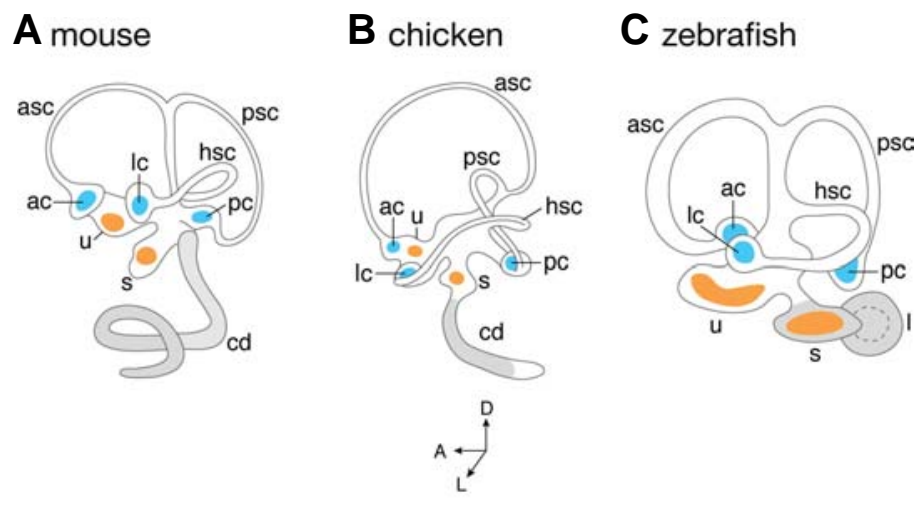

Fig. 1. Structure of the adult inner ear. Morphology of the membranous labyrinth in three vertebrate species: mouse (A), chicken (B) and zebrafish (C). The vestibular (dorsal) part of the membranous labyrinth contains five sensory organs: the three cristae (blue) located at the basis of the three semicircular canals and the utricular and saccular maculae (orange), surrounded by otoliths. The ventral, auditory part of the inner ear (grey) is highly variable in morphology and complexity in different vertebrates. In the mouse, the cochlear duct, a coiled structure, contains a finely patterned sensory organ, the organ of Corti. In chicken, the auditory organ, the basilar papilla, is also contained in the cochlear duct. In zebrafish, there is no ventral cochlear duct and the auditory function is carried by the saccular and lagenar maculae. The endolymphatic sac and duct (not represented) produce the endolymph, which circulates in the membranous labyrinth. ac: anterior crista; asc: anterior semicircular canal; cd: cochlear duct; hsc: horizontal semicircular canal; I: lagena; Ic: lateral crista; pc: posterior crista; psc: posterior semicircular canal; s: saccule; u: utricle. The embryonic axes are indicated at the bottom. ovestibular ganglion in mouse). The SAG forms anteroventrally to the otocyst (Figure $2 \mathrm{~d}$ ). The kinetics of neuron production and sensory patches formation is not the same in different species. In amniotes, neurogenesis and neuronal delamination from the otic epithelium begin at cup stage (Figure 2Ab-d). Sensory organs are formed later. In zebrafish, neurogenesis and first hair cell formation occur simultaneously. Cells giving rise to the neurons of the SAG are derived from the ventral floor of the otic vesicle (Haddon and Lewis, 1996). Delamination takes place in the anteroventral region and the SAG is then localised anteroventrally to the otocyst (Figure 2Bc-d). At the same time, the first hair cells -called tether cells- form in two patches, the utricular (anteroventral) and saccular (posteromedial) maculae. These two patches can be distinguished by their position (more medial for the saccular macula) and shape and by the different orientation patterns of their hair cells. Thus, in this species, the SAG and the first sensory patches define anterior and posterior, as well as dorsal and ventral poles as soon as the otic vesicle stage (Figure $2 \mathrm{Be}$ ). Later, the cristae will form in anterior, posterior and medial positions along the lateral wall of the vesicle (Figure $2 \mathrm{Be}$ ). In amniotes, the mediodorsal part of the vesicle is marked by the early appearance of the endolymphatic duct (Figure 2Ad-e), while in zebrafish, this duct appears only later in development. After $10.5 \mathrm{dpc}$ in mouse (E3.5 in chick), the vesicle is elongated along the DV axis, with the ventral part prefiguring the cochlear duct (Figure 2Ac) (Cantos et al., 2000).

The multiplicity of cell types formed in the otocyst, the fact that these different cell types arise from specific regions of a single epithelium, as well as the complex morphogenesis taking place in this organ, underline the importance of integrating regionalization and cell type specification in the developing ear.

\section{Axial specification in the inner ear and its relationship to cell fate}

As mentioned above, the cells of the developing inner ear undergo a sequence of cell fate decisions to generate all different cell types from a single otic epithelium and the cell types must arise in the correct spatial position with respect to one another. It is tempting to speculate that this occurs similarly to the adjacent hindbrain, where compartment formation and establishment of positional identity direct cell fate specification (SchneiderMaunoury et al., 1998; and see below). A compartment based model has indeed been proposed for cell specification in the inner ear (Brigande et al., 2000a; Brigande et al., 2000b). However, how the axes of the otocyst are established and where the positional cues come from is a field under current investigation. We summarize below several lines of evidence suggesting that, early on, the otic placode and vesicle are already regionalised along their different axes.

\section{Early molecular asymmetries}

Molecular asymmetries precede morphological asymmetries; by the otic vesicle stage, several gene expression domains compartmentalize the otocyst along its three axes. Genes that are expressed within the early otocyst are thought to specify the future regions of the ear (reviewed by Fekete and Wu, 2002) and typically encode transcription factors. For some of these genes, functional studies have been performed, thus allowing to corre- 

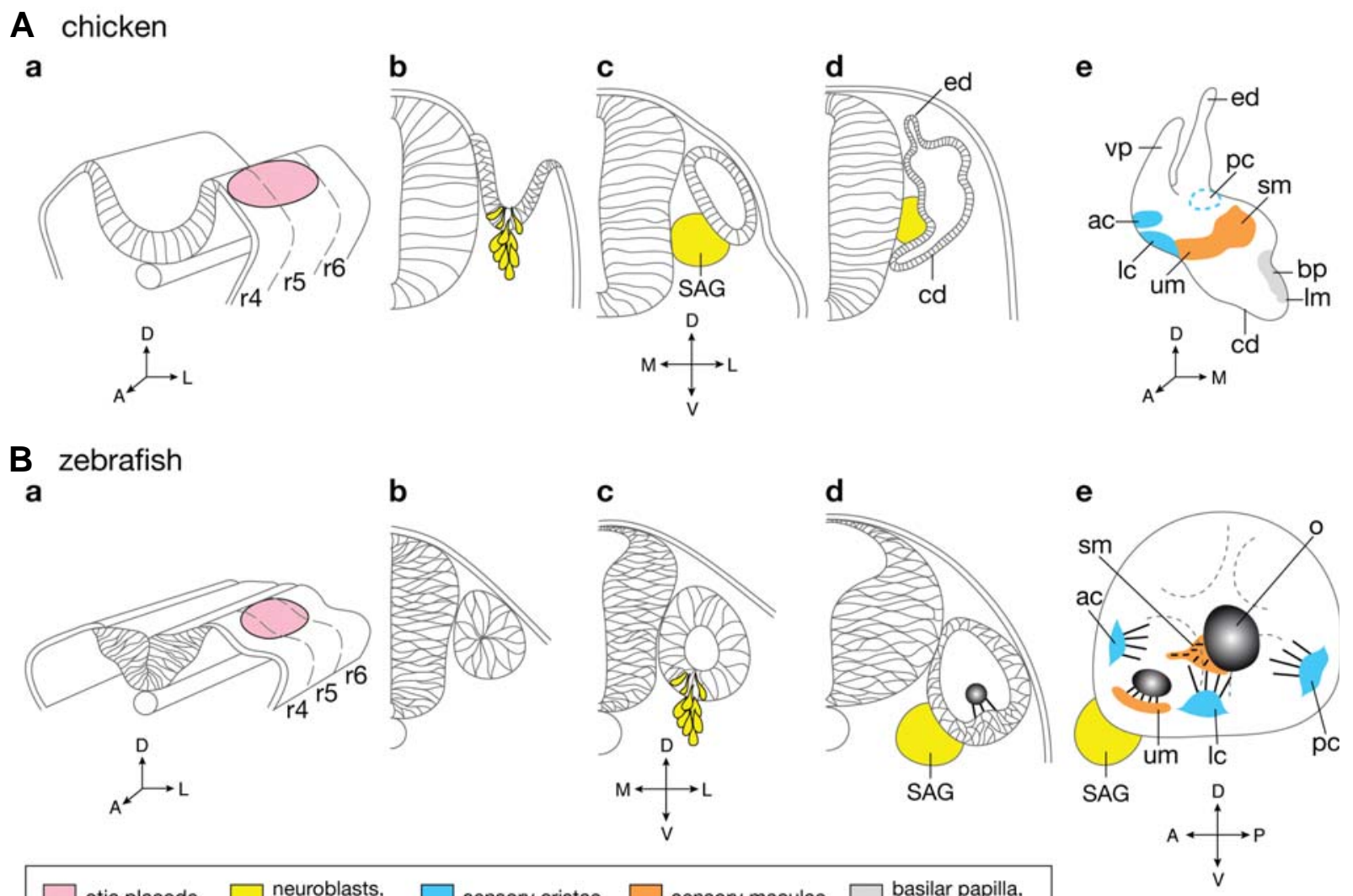

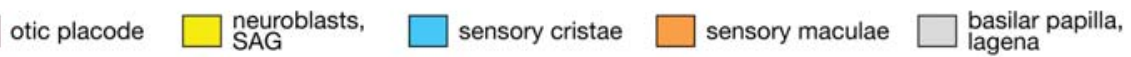

Fig. 2. Early development of the inner ear.Schematic drawings of the development of the inner ear in chicken (A) and zebrafish (B). The development of the mouse inner ear is similar to that of chicken. (a) 3D representations of a transverse segment of the head region. (b-d) Transverse sections at otic level. (e) Diagrammatic representations of the chick inner ear at E5 and of the zebrafish larval ear. The otic placode is pink, the neuroblasts and SAG are yellow, the sensory cristae are blue, the sensory maculae are orange and the basilar papilla and lagena are grey. Abbreviations: ac, anterior crista; bp, basilar papilla; cd, cochlear duct; ed, endolymphatic duct; lc, lateral crista; Im, lagenar macula; o, otolith; pc, posterior crista; $r$, rhombomere; SAG, statoacoustic ganglion; sm, saccular macula; um, utricular macula; vp, vertical pouch (semicircular canal primordium). The dotted lines in (Be) represent the epithelial protrusions that will form the semicircular canals; Stages in (A) are: $10 \mathrm{~s}(\mathrm{a}), 19 \mathrm{~s}(\mathrm{~b}), 30 \mathrm{~s}(\mathrm{c}), \mathrm{E} 3.5$ (d) and E5 (e). Stages in (B) are: 10s (14 hpf) (a); $14 \mathrm{~s} \mathrm{(16} \mathrm{hpf)} \mathrm{(b);} 26 \mathrm{~s}$ (22 hpf) (c); 30 hpf in (d), $120 \mathrm{hpf}$ in (e). hpf means hours post-fertilization at $28^{\circ} \mathrm{C}$. The embryonic axes are indicated underneath each drawing. Axes in $A$ and $B$ are the same.

late the early gene expression domains with the functions of these genes in otic patterning, cell fate, and/or cell survival and proliferation.

In mouse and chicken, molecular asymmetries along the DV axis are observed early on (Figure $3 \mathrm{Aa}$ ). The ventral cells of the otic vesicle are marked by expression of Otx1, Otx2 and Pax2, while the dorsal cells express $H m x 2, H m x 3$ (formerly named Nkx5. 1), Dlx5and Gbx2(Lin et al., 2005; for review see Brigande et al., 2000). Inactivation of these genes in the mouse confirms that they participate in establishing the dorsal (vestibular) and the ventral (cochlea) components, mainly through the control of cell survival and proliferation during ear morphogenesis. For example, Pax2 mutants show agenesis of the cochlea and of the spiral (auditory) ganglion (Torres et al., 1996) due to a reduction of cell proliferation (Burton etal., 2004). The loss of Otx1 and Otx2 also affects the cochlea, as well as the development and the final positioning of some of the sensory organs within the mouse inner ear (Morsli et al., 1999). In contrast, the dorsally expressed genes $D / \times 5, H m \times 2 a n d H m \times 3 a r e$ essential for vestibular morphogenesis (Wang et al., 1998; Wang et al., 2001; Merlo et al., 2002). Gbx2 has a cell-autonomous effect in the development of the endolymphatic duct and vestibular structures (Lin et al., 2005).

In zebrafish, molecular asymmetries along the three axes are apparent before $20 \mathrm{hpf}$ (Figure 3B). $n k \times 5.1 / \mathrm{hm} \times 3$, the first known asymmetrically expressed gene, is induced in a large anterior region of the placode and vesicle from $14 \mathrm{ss}$ (16 hpf) onwards (Adamska et al., 2000). Later, several markers are specifically expressed in anterior (pax5, fgf8), posterior (follistatin, bmp $)$, medial (pax2a), dorsal (dachaand $d / x 3 b$ ) and ventral (otx1, eya1, six 1) regions of the vesicle (Krauss et al., 1991; Akimenko et al., 1994; Bauer and Goetz, 1998; Pfeffer et al., 1998; Reifers et al., 1998; Sahly et al., 1999; Mowbray et al., 2001; Hammond et al., 2002; Bricaud and Collazo, 2006). The function of several of these genes has been addressed using morpholino injection and/or mutants. Interestingly, they are not only involved in ear patterning but, also, in regulating cell proliferation and apoptosis. Loss of function of pax5 leads to impairment of vestibular functions due to hair cell death in the utricular macula (Kwak et al., 2006). Analysis of the dog-eared mutants (dog) shows that eya1 is involved in survival of sensory hair cells, particularly in the cristae 
(Kozlowski et al., 2005). six 1 expression in the ventral otic vesicle has contrasting roles on neuronal and hair cell lineages: it promotes hair cell formation by increasing cell proliferation and inhibits neuronal formation by inducing apoptosis (Bricaud and Collazo, 2006).

Not surprisingly, genes involved in cell fate specification are also expressed in region-specific patterns. In amniotes, the specification of some otocyst cells as neuroblasts at the otic cup stage is perhaps the earliest cell fate decision that takes place in the ear (Figure 3Ab) (Ma et al., 1998). In chick, Fgf10 precedes the expression of the proneural genes $n g n 1$ and neuroD in the neurogenic domain, which corresponds to the ventral anteromedial quadrant of the otic primordium. Fgf10 expression in this region is required for neuronal formation (Alsina et al., 2004) although it is not the only player, since Fgf10 null mice have normal initial

\section{A amniotes}

a axial specification
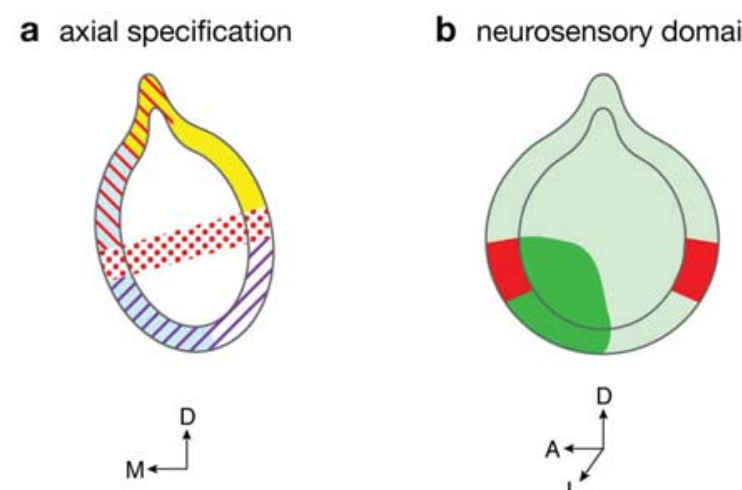

Pax2

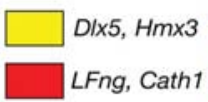

MIGbx2 $\square$ LFng, Cath1
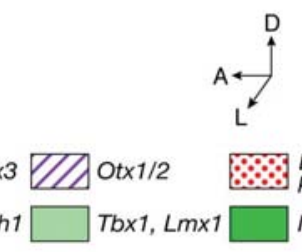

$\because 3$ Bmp4

prosensory domain

Ngn1, NeuroD

\section{B zebrafish}

a axial specification
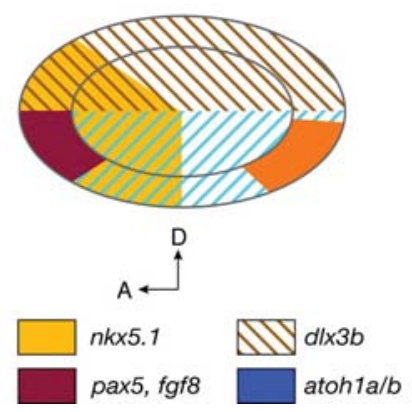

b neurosensory domains
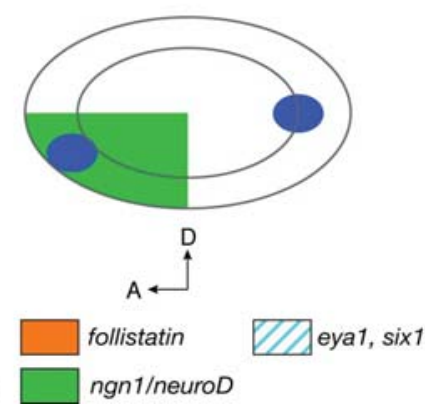

Fig. 3. Early regionalization and cell fate specification markers in the otocyst of amniotes and zebrafish. (A) Schematic drawings of amniotes otic vesicles. (Aa) represents a transverse section at E2-3 in chick and $(A b)$ shows a lateral view at E2-3. (B) Schematic lateral views of the zebrafish otic vesicle at $24 \mathrm{hpf}$. (Ba) represents gene expression domains regionalized along the $A P$ and $D V$ axes; $(B b)$ shows early markers of neurogenic and sensory specification. Gene expression domains that prefigure different regions of the inner ear, as well as cell fate markers are color-coded. Embryonic axes are indicated. neurogenesis (Pauley et al., 2003). In the mouse, Tbx1 is expressed in the posterior region of the otic cup and vesicle and is required to delimit the neurogenic domain (Raft et al., 2004; Xu et al., 2007). Markers of sensory cell fate in amniotes appear later than those of neuronal fate and are marked by the expression of neurotrophins BDNF and NT-3, Bmp4, LFng, Ser1 and Cath1 (Figure 3A, Figure 2Ae) (Wu etal., 1998; Cole etal., 2000; Fariñas et al., 2001; Pujades et al., 2006).

In zebrafish, the sensory and neuronal lineages both arise from the ventral part of the vesicle and genes involved in the formation of sensory and neuronal progenitors are expressed very early in the ventral region of the otocyst (Figure $3 \mathrm{Bb}$ ). The proneural genes ngn 1 and neuroD, which mark neuronal progenitor cells and are necessary for formation of the SAG, are expressed in the anteroventral region of the otocyst (Andermann et al., 2002), while atoh $1 a / b$, markers of sensory progenitor cells, are expressed as soon as the placode stage in groups of cells, one anterior and one posterior, prefiguring the utricular and saccular maculae, respectively. atoh $1 a / b a r e$ necessary for hair cell formation in all sensory patches, thereby playing a classic role of proneural genes in the ear (Millimaki et al., 2007). The cristae arise later and are marked by the expression of bmp pathway members (Mowbray et al., 2001).

\section{Temporal programme of otic patterning}

It is tempting to assume that early molecular asymmetries prefigure later ear patterning and in some cases this is confirmed by the analysis of mouse mutants. However, the existence of an asymmetry (morphological or molecular) at early stages does not imply that the regional fate of the cells is already determined. First, cell dispersion and/or active migration may prevent this regional specification or may change the position of cell groups relative to the axes. Second, definitive regional specification may depend on different signals acting over a large temporal window. Therefore, two important questions to ask are: 1) where and when is cell dispersion and migration restricted in the otocyst and 2) when do the axes of the inner ear become fixed during development?

In an attempt to answer the first question, fate maps of the otic primordium have been performed in different species and at different stages (Brigande et al., 2000; Lang and Fekete, 2001; Kil and Collazo, 2001; Streit, 2002; Kozlowski etal., 1997; Satoh and Fekete, 2005; Abello et al., 2007; reviewed in Kil and Collazo, 2002). However, the results obtained so far fail to give a clear picture. For instance, in Xenopus, a fate map of the sensory organs performed at otocyst stage has shown a high degree of cell dispersion along the AP and DV axes (Kil and Collazo, 2001), while in chick, a fate map of the rim of the otic cup has identified lineage boundaries, leading to a compartment model for inner ear patterning (Brigande etal., 2000b; Satoh and Fekete, 2005). More experiments will be required to determine, first, at what stage cell dispersion becomes restricted in the otocyst in different species and second, if the establishment of lineage boundaries is an important event in inner ear regionalization, as it happens during segmentation of the adjacent hindbrain.

The timing of otic axis specification was addressed in chick by axial rotations of otic cups and vesicles. These works suggested that the DV axis is established later than the AP axis (Wu et al., 1998; Bok et al., 2005). Moreover, the AP axis seems to be established earlier for sensory structures than for non-sensory 
structures. Although these data need to be extended by using more and/or earlier markers of different ear structures, they argue in favour of a multistep process of axis establishment acting on a relatively large temporal window and probably involving many different signals.

\section{Caudal hindbrain patterning}

During neurulation in vertebrates, the hindbrain is transiently subdivided along its AP axis into a series of $7 / 8$ segments termed rhombomeres, which are compartments of cell lineage restriction. This segmentation process sets up the stereotyped pattern of neuronal specification in the brainstem. It is also involved in neural crest cell migration in three streams towards the pharyngeal arches, thereby influencing craniofacial morphogenesis. A number of regulatory genes are expressed in specific rhombomeres or groups of rhombomeres and many of them have been implicated in different steps of the segmentation process (for review Schneider-Maunoury et al., 1998). Here we review the molecular mechanisms of formation of rhombomeres 4 to 6 , the hindbrain region directly adjacent to the developing otocyst (Figure 4), with greater interest for the genes whose functional studies have indicated a role of the hindbrain in inner ear patterning.

The hindbrain is patterned under the influence of two major signaling pathways, the FGF and retinoid pathways. FGFs are synthesized at the midbrain-hindbrain boundary region and also in different rhombomeres and play a role in the specification of adjacent domains (see below). Retinoic acid (RA) is synthesized in the anterior somitic mesoderm and plays and essential role in setting up AP positional information in the hindbrain (reviewed in Glover et al., 2006). RA controls, directly and indirectly, the expression of several genes in the hindbrain, among which several Hox genes, vhnf1 and MafB. In particular, they directly control Hox genes of the paralogous groups 1 and 4 (Marshall et al., 1994; Gould et al., 1998).

During the last 15 years, the molecular mechanisms of hindbrain patterning have been extensively studied in the mouse by the means of knock-out mutants and transgenesis. These studies have identified Hox genes as major actors in the control of AP identity in the hindbrain and pharyngeal arches (for review Schneider-Maunoury etal., 1998; Trainor and Krumlauf, 2001). The 4 first groups of Hoxparalogues (1-4) are expressed in the hindbrain, with temporal and spatial patterns that depend on their position in the clusters. One of the Hox genes, Hoxa 1, plays an early and central role in formation of the caudal hindbrain illustrated by the strong reduction of $r 4$ and r5 in Hoxa1 mutants (Dolle et al.,
1993; Helmbacher etal., 1998). Another essential gene for caudal hindbrain patterning is MafB, which codes for a bZIP transcription factor and is expressed in prospective $r 5$ and $r 6$. The phenotype of MafB loss-of-function has first been studied in the mouse mutant kreisler, named accordingly to its circling behavior. In the hindbrain, the kreisler mutant displays a loss of r5 and a misspecification of $r 6$ (McKay et al., 1994; Sadl et al., 2003). kreisler is not a null mutant for MafB but rather a regulation mutant, which abolishes MafBexpression in r5/r6 and activates it in r3 (Eichmann et al., 1997; Giudicelli et al., 2003). More recently however, the essential function of MafBin regulating the maintenance and expansion of $r 5$ and specification of $r 6$ has been confirmed using a mouse mutant obtained by ENU mutagenesis (Sadl et al., 2003) and in zebrafish, where several mutant alleles of valentino (val), the zebrafish MafBgene, have been obtained (Moens et al., 1998; Prince et al., 1998). Among other regulatory functions, $M a f B$ is necessary for the expression in r5 of krox20, a gene required for the formation and specification of $r 3$ and $r 5$ (Schneider-Maunoury et al., 1993; Schneider-Maunoury et al., 1997; Voiculescu et al., 2001).

Recently, studies performed in the zebrafish embryo have allowed identifying early events of caudal hindbrain formation and patterning. In particular, they have uncovered the essential functions of the transcription factor vhnf1 and of FGF signaling in

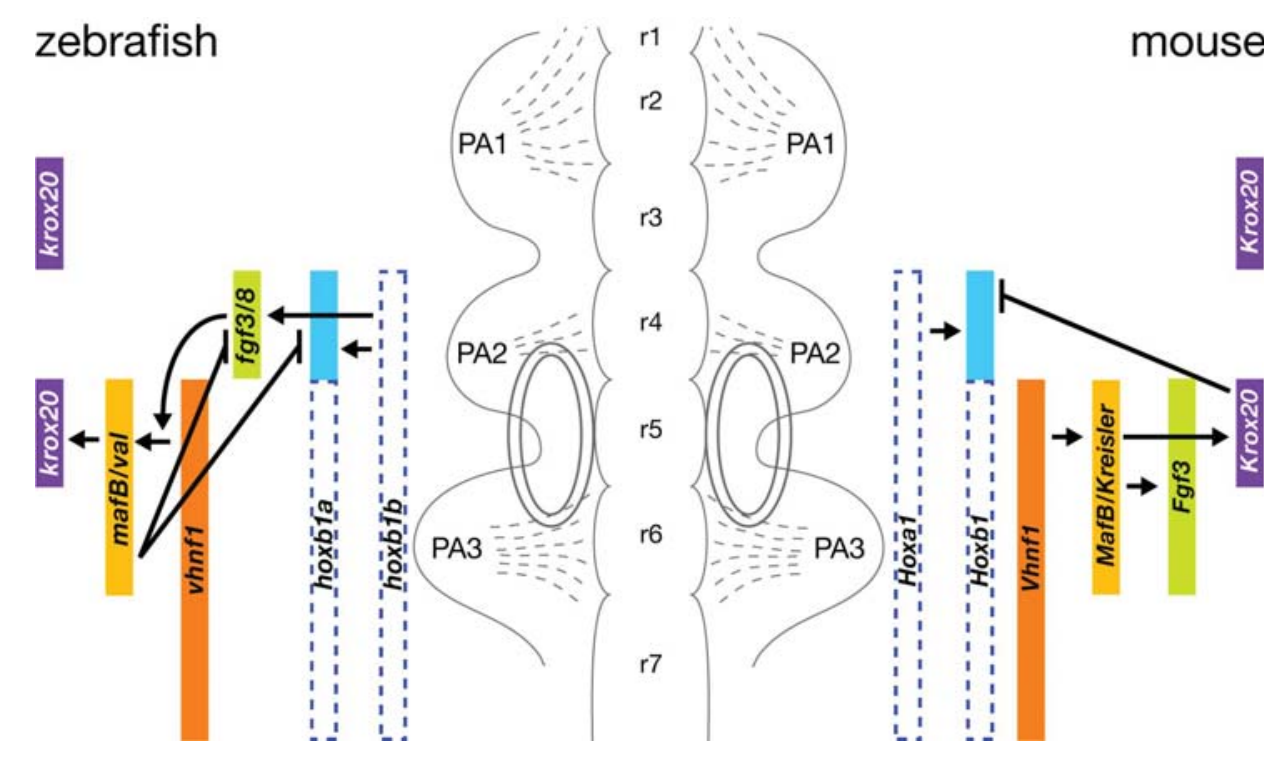

Fig. 4. Caudal hindbrain patterning. A schematic vertebrate hindbrain region is presented, with rhombomeres ( 1 1-r7), the three first pharyngeal arches (PA1-3), the three streams of migrating neural crest cells (dotted lines) and the bilateral otic vesicles. Crest cells from r1-r2 migrate into PA1, crest cells from r4 migrate into PA2 and crest cells from r5 and r6 migrate into PA3. The expression patterns of regulatory genes are indicated and color-coded on the left for zebrafish and on the right for the mouse. The dotted lines for Hox genes indicate a transient expression, which is downregulated before the onset of morphologic segmentation: Hoxa1 (hoxb1 b in zebrafish) and its paralogue Hoxb1 (hoxb1a in zebrafish) are activated at mid-gastrulation and present an anterior limit in the neural plate in the prospective hindbrain region, which later coincides with the $r 3 / r 4$ boundary. Contrary to Hoxa1, Hoxb1 is maintained in $r 4$ after the end of gastrulation and this expression in r 4 requires Hoxa1 function. Regulatory interactions between the different genes are indicated. Arrows represent positive regulations and vertical bars represent negative regulations. Some of these regulatory interactions, but not all, have been shown to be direct. Note that some expression patterns (e.g. for Fgf genes) and regulatory interactions are different in these two species. Anterior is to the top. 
caudal hindbrain specification. The vhnf1 (Hnf1//Tcf2) gene codes for a homeodomain transcription factor. In the neural plate, vhnf1 is expressed from the end of gastrulation onward, with an anterior expression limit at the prospective $r 4 / r 5$ boundary. The study of a vhnf1 insertional mutant in zebrafish has shown the involvement of this factor in caudal hindbrain formation (Sun and Hopkins, 2001). In vhnf1 homozygous embryos, valexpression in r5-r6 and krox20 expression in $r 5$ are severely reduced or absent. Notably, r4 markers such as hoxb1a and fgf3 are expanded caudally as in $v a /$ mutants. Therefore, $v h n f 1$ is involved in specification of r5-r6 and in the repression of $r 4$ identity (Wiellette and Sive, 2003; Hernandez et al., 2004).

FGF signaling is essential for caudal hindbrain patterning. In zebrafish, two fgfgenes, fgf3and $f g f 8$, are expressed in prospective $r 4$. Loss-of-function studies in this species showed that $f g f 3$ and $f g f 8$ are required for the activation of $v a /$ expression in $\mathrm{r} 5-\mathrm{r} 6$ and krox20 expression in r5 (Maves et al., 2002; Walshe et al., 2002). Moreover, FGF signals from r4 have been shown to synergize with $v h n f 1$ for this activation (Wiellette and Sive, 2003; Hernandez et al., 2004). Thus, by secreting FGF signals, r4 forms a signaling centre involved in caudal hindbrain patterning, in particular in valand krox20activation. Although Fgfgene expression patterns in the hindbrain of amniotes differ from that of zebrafish (see below), FGF signaling in chick embryos has also been involved in hindbrain patterning, particularly in the regulation of MafB and Krox20 expression (Marin and Charnay, 2000; Aragon et al., 2005).

The functional data obtained in different vertebrates can be combined into a regulatory hierarchy involved in caudal hindbrain formation (Figure 4). However, it should be mentioned that several data have been obtained in only one vertebrate species. Moreover, in some cases, differences have been found in the gene expression patterns and/or in the functional data in amniotes and in zebrafish. One important difference lies in the expression of $f g f 3$ and its regulation by segmentation genes. In the mouse, Fgf3 is expressed at early somite stages in $\mathrm{r} 4$ and in the surface ectoderm including the prospective otic placode region. Later, its high level expression domain in the hindbrain restricts to 5 and $r 6$ (Mahmood et al., 1996). MafBis necessary for Fgf3 expression in the r5-r6 domain (McKay et al., 1996). In contrast, in fish fgf3 is expressed in $r 4$ (Maves et al., 2002; Walshe et al., 2002) and its expression in the valand vhnf1 mutants extends posteriorly (Kwak et al., 2002; Wiellette and Sive, 2003; Hernandez et al., 2004; Lecaudey et al., 2007). Thus, the caudal hindbrain in zebrafish MafB/val mutants expresses fgf3 ectopically, whereas in MafB/kreis/er mutant mice, the caudal hindbrain shows reduced Fgf3levels (McKay et al., 1996).

In addition to AP patterning, the hindbrain is also regionalized along its DV axis. The mechanisms of neural tube DV patterning have been extensively studied in the spinal cord (for review Lee and Jessell, 1999; Jessell, 2000) and similar mechanisms are thought to function in the hindbrain. In particular, $\mathrm{Hh}$ signaling from the notochord and floor plate and Wnt and BMP signaling from the ectoderm, dorsal neural tube and roof plate, control the nested expression of a series of transcription factors along the DV axis of the spinal cord. These transcription factors, through complex regulatory interactions, establish distinct neuronal progenitor domains. Recent data have shown that in the hindbrain, the integration of AP and DV molecular inputs provides a two-dimensional grid of coordinates for motor neuron progenitor specification (Samad et al., 2004).

\section{Hindbrain segmentation and otic development: insights from functional data}

Tissues surrounding the inner ear, such as the hindbrain, mesoderm and endoderm, have been implicated in conferring signals required for inner ear development (Giraldez, 1998; Fekete, 1999; Kiernan et al., 2002). An essential function of the hindbrain has been demonstrated by the analysis of mutants of regulatory genes expressed in this tissue -but not in the otic tissue- and involved in caudal hindbrain segmentation, such as MafB, vHnf1 and Hoxa1. The contribution of these functional studies is summarized below (Figure 5). In all cases, the inner ear defects are attributed to defects in rhombomeres 4 to 6 , the region of the hindbrain juxtaposing the developing otocyst (Figure 2). While there are several discrepancies between the results obtained in different species, all the data point to an essential role of signaling from the hindbrain and in particular FGF signaling, in otic regionalization.

In mice, important information about hindbrain signals was brought by analysis of the kreisler mutant, in which MafB gene expression in $r 5$ and $r 6$ is abolished. kreisler mice are deaf, present a circling behavior and show many defects in otic development. Since MafB is not expressed in the otocyst, it has been proposed that the deficit in FGF3 signaling was a main cause of the otic defects seen in kreisler (McKay et al., 1996). In these mice, dorsomedial markers such as Gbx2 and Wnt2b are lost, while the ventral Otx2domain is expanded. Later, the cochlea is expanded and the endolymphatic duct and sac are absent, suggesting a role of the hindbrain in specifying dorsomedial structures of the inner ear (Choo et al., 2006). The role of FGF3 as a hindbrain signal in ear patterning is consistent with the analysis of the Hoxa1 mutant, in which the appearance of ear patterning defects is also correlated to the loss of Fgf3expression in the hindbrain (Pasqualetti et al., 2001).

In contrast to the situation in mouse, the MafB/va/mutation in zebrafish results mainly in AP patterning defects (Kwak et al., 2002). Anterior markers such as $h m \times 3$ are expanded posteriorly, while caudal markers are reduced or absent. va/mutants also present an excess of hair cells, ectopically produced between the anterior and posterior maculae (Kwak et al., 2002). Surprisingly, although the $\mathrm{va}$ /mutation clearly affects AP patterning of the ear, it does not lead to an increase in the size of the SAG, suggesting that SAG formation is under a tight, hindbrain-independent, control. As mentioned above, the va/mutation results in a posterior expansion of fgf3 expression in the hindbrain. Reduction of fgf3RNA levels in va/mutants using morpholinos rescues some of the otic defects, strongly suggesting that, in zebrafish as well as in mouse, FGF3 is a major signal involved in ear patterning downstream of MafB.

The analysis of the zebrafish vhnf1 mutant adds more complexity to the picture. As shown earlier, vhnf1 positively controls val expression in the hindbrain. As expected, AP patterning phenotypes are observed in the inner ear of $v h n f 1$ mutants, which display an expansion or a duplication of anterior otic markers such as $h m \times 3$, fgf8 and pax5. However, vhnf1 mutants also show DV 


\begin{tabular}{|c|c|c|}
\hline GENE EXPRESSION PROFILE & NEURAL TUBE PHENOTYPE & OTIC PHENOTYPE \\
\hline $\begin{array}{l}\text { Transcription factors } \\
\text { (ov }\end{array}$ & $\begin{array}{l}\text { Mouse mutant: } \\
\text { Reduction of } \mathrm{r} 4 \text { and absence of } \mathrm{r} 5 \\
\text { Loss of } F g f 3 \text { expression in caudal hindbrain }\end{array}$ & $\begin{array}{l}\text { Small otic vesicles displaced from the hindbrain } \\
\text { Defects in vestibular and cochlear structures }\end{array}$ \\
\hline$\overbrace{\text { vinf1 up to } r 4 / 55}^{5}$ & $\begin{array}{l}\text { Conditional mouse mutant: } \\
\text { Posterior expansion of Hoxb1 expression } \\
\text { Zebrafish mutants: } \\
\text { Defects in caudal hindbrain specification } \\
\text { Posterior expansion of fgf3 }\end{array}$ & $\begin{array}{l}\text { ND } \\
\text { Expansion/duplication of anterior domain } \\
\text { Dorsal shift of sensory cell groups } \\
\text { Presence of hair cells at ectopic positions }\end{array}$ \\
\hline$\overbrace{\text { MafB/kreisler }+5, r 6} \int^{5} 6$ & $\begin{array}{l}\text { kreisler mouse mutant: } \\
\text { Loss of } \mathrm{r} 5 \text { and defects in } \mathrm{r} 6 \text { specification } \\
\text { Posterior expansion of } \mathrm{r} 4 \\
\text { Loss of } F g f 3 \text { expression in caudal hindbrain } \\
\text { Zebrafish val mutants: } \\
\text { Misspecification of } r 5 \text { and } r 6 \\
\text { Posterior expansion of fgf3 expression }\end{array}$ & $\begin{array}{l}\text { Absence of dorsomedial, vestibular structures } \\
\text { Expansion of ventral, cochlear structures } \\
\text { Expansion of anterior domain } \\
\text { Presence of hair cells at ectopic locations }\end{array}$ \\
\hline Secreted molecules & $\begin{array}{l}\text { Loss-of-function of fgf3 and fgf8 in zebrafish: } \\
\text { Defects in r5/r6 specification } \\
\text { Loss of val (r5-r6) and krx20 (r5) expression }\end{array}$ & $\begin{array}{l}\text { Smaller ears } \\
\text { Abnomal semicircular canals } \\
\text { Smaller neurogenic and sensory domains }\end{array}$ \\
\hline$\sqrt[5]{6}$ & $\begin{array}{l}\text { Fgf3/Fgf10 compound mice mutants: } \\
\text { No changes in caudal hindbrain patterning }\end{array}$ & Defects in otic induction \\
\hline Shh fp+not & $\begin{array}{l}\text { Mouse mutant: } \\
\text { Loss of ventral cell fates in the neural tube } \\
\text { Loss-of-function of the Hh pathway in zebrafish: } \\
\text { Defects in ventral cell fates in the neural tube }\end{array}$ & $\begin{array}{l}\text { Loss of neuronal progenitors and SAG } \\
\text { Loss-of-function of the Hh pathway: } \\
\text { Loss of anterior structures } \\
\text { Gain-of-function of the Hh pathway: } \\
\text { Mirror image duplications of anterior structures }\end{array}$ \\
\hline$\underbrace{}_{W n t r p+d n r} ل_{1}^{1}$ & $\begin{array}{l}\text { Compound Wnt1/Wnt3a mutants: } \\
\text { Reduction of dorsal neural tube and neural crest } \\
\text { derivatives }\end{array}$ & $\begin{array}{l}\text { Loss of dorsal, vestibular structures } \\
\text { Defects in the cochlea }\end{array}$ \\
\hline
\end{tabular}

Fig. 5. Neural tube mutations affecting otic development. The first column shows gene expression profiles in the neural tube of mice and zebrafish embryos. The second column indicates the hindbrain phenotype observed in the corresponding mutants. The third column summarizes the otic phenotypes described for those mutations. Genes are organized depending if they code for transcription factors or secreted molecules. Results obtained in zebrafish are indicated in italics. All the summarized data correspond to references quoted all along the review except for Sirbu et al., 2005. In schemes in the first column, anterior is to the left.

patterning defects, with an expansion of ventral markers at the expense of dorsal markers and a dorsal shift of intermediate markers such as atoh1a, which marks the future maculae. Most probably as a consequence of these patterning defects, hair cells form at ectopic positions in the center of the vesicle (Lecaudey et al., 2007). Following this study, we reinvestigated DV patterning in $\mathrm{va}$ /mutants and found defects similar to those found in $v h n f 1$ mutants (Lecaudey et al., 2007; S. Schneider-Maunoury and C. Pujades, unpublished results).

In conclusion, analyses of mutants for different hindbrain segmentation genes in both zebrafish and mice point to a role of hindbrain signaling downstream of these genes. However, there is a striking difference between the two species. The main defects seen in mice are along the DV axis, while in zebrafish, defects have been found primarily along the AP axis. However, this difference may be only apparent, since a closer examination of the mutants has allowed to detect DV patterning defects in both vhnf1 and va/zebrafish mutants. Further insight into the role of hindbrain in otic patterning is brought by the functional analysis of signaling pathways potentially involved.

\section{The hindbrain as a source of instructing molecules for otic regionalization}

Three main signaling pathways, the Hedgehog ( $\mathrm{Hh})$, Wnt and FGF pathways, have been involved in otic patterning from the adjacent hindbrain. Hhgenes are expressed in the floor plate and underlying notochord. Wntgenes, in particular Wnt1 and Wnt3a, are present in the dorsal neural tube in all vertebrates. As mentioned before, several Fgfgenes are expressed in the hindbrain, with species-specific patterns.

The function of FGFs in otic development has been extensively 
studied. Both in amniotes and in fish, the loss of function of $F g f$ genes leads to smaller and malformed otic vesicles, demonstrating a role for this signaling pathway in otic induction (Represa et al., 1991; Vendrell et al., 2000; Adamska et al., 2000; Phillips et al., 2001; Leger and Brand, 2002; Maroon et al., 2002; Alvarez et al., 2003; Wright and Mansour, 2003; Liu et al., 2003; Hans et al., 2004; Phillips et al., 2004; Millimaki et al., 2007). This function is attributed mainly to FGF signals from the hindbrain in zebrafish, while in amniotes, other surrounding tissues such as the mesenchyme and endoderm are also a source of FGFs (Ladher et al., 2006). FGF target genes are expressed in the otic epithelium, suggesting a direct effect of this signaling pathway (Chambers et al., 2000; Raible and Brand, 2001; F. Aragon and C. Pujades, unpublished results). The redundancy between different FGFs and their role in otic induction have hampered the analysis of their role in otocyst regionalization. Thus, the best indication so far of FGF function in otic patterning comes from the analysis of mutants of hindbrain segmentation genes such as MafB, Hoxa1 and $v H n f 1$. As mentioned above, in these mutants, there is a strong correlation between loss-of-function or gain-of-function of FGF in the hindbrain and otic patterning defects. Moreover, in val mutants, part of the defects appears to be rescued by depletion of fgf3 function.

Shh signaling from the notochord and floor plate is essential for ear patterning in mice (Riccomagno etal., 2002). The study of Shh mutants shows that this signaling pathway is required for the formation of the cochlea, a ventral otocyst-derived structure. In Shh mutant embryos, ventral Otx $1 / 2$ expression is reduced and dorsal $D / x 5$ expression is expanded ventrally. Medial Pax2 expression is also lost. While sensory specification is not affected, proneural gene expression is strongly reduced and the SAG is absent. The reverse phenotype is seen after missexpression of Shh in the otocyst using transgenic mice: dorsal, vestibular structures are lost and ventral, auditory cell fates are expanded. Accordingly, Pax2 is expanded laterally and dorsal $D / x 5$ and Hmx3 expression is lost. Interestingly, neurogenesis appears increased and the SAG is larger. These results led the authors to propose that Shh instructs ventral fates, but differently along the AP axis: anteriorly it activates $\mathrm{Ngn} 1$ and NeuroD promoting neurogenesis, while posteriorly it activates Pax2and Otx1/2 and promotes cochlear fate (Riccomagno et al., 2002). The Hh signaling targets Gli1 and Ptc1 are expressed broadly in the otic epithelium suggesting that $\mathrm{Hh}$ signaling may act directly. A recent paper suggests that different levels of Shh activity mediate the formation of inner ear structures, with Gli3 repressor required dorsally for vestibular formation and Gli activators functioning ventrally to form the cochlear duct (Bok et al., 2007).

Surprisingly, manipulating the Hh signaling pathway in zebrafish results, not in DV or ML, but in AP patterning defects (Hammond et al., 2003). Two strong $\mathrm{Hh}$ pathway mutants exhibit a striking partial mirror image duplication of some anterior otic markers and of anterior sensory structures such as the utricular macula, concomitant with a loss of posterior otic domains. The SAG, however, is not duplicated. Hh signaling from both floor plate and notochord needs to be abolished to obtain this phenotype. The reverse phenotype, namely expansion of posterior structures at the expense of anterior ones, is obtained when the Hh pathway is constitutively activated by overexpression of Shh or by injection of a dominant negative form of PKA. Based on the expression

\section{A amniotes}
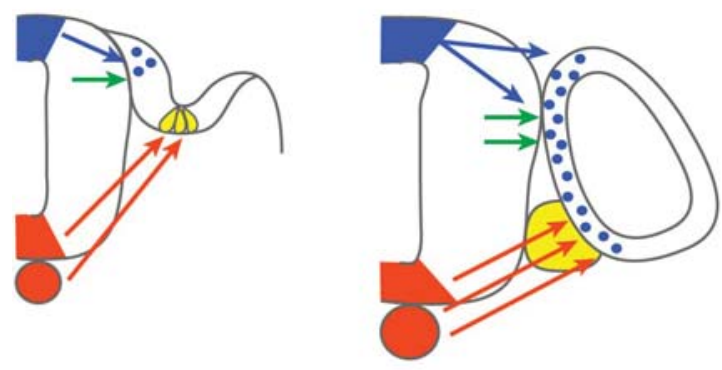

a cup stage, r5-r6 level

b vesicle stage, r5-r6 level

\section{B zebrafish}
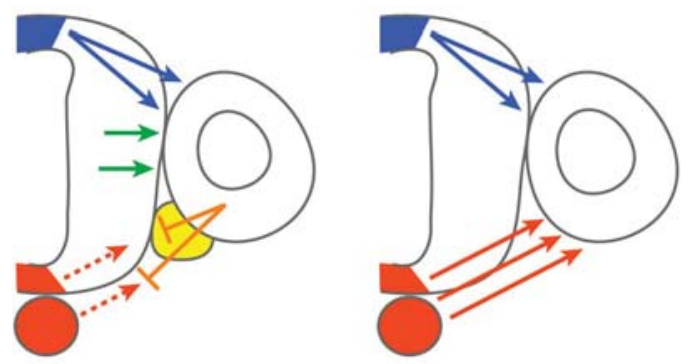

a vesicle stage, r4 level

b vesicle stage, r5-r6 level

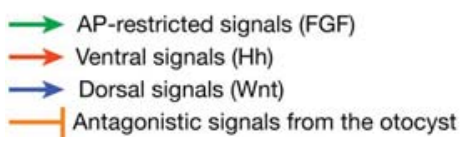

Fig. 6. Hindbrain signals involved in inner ear patterning in zebrafish and amniotes: current models. (A) In amniotes, the otic cup is positioned close to the dorsal half of the neural tube. At early stages of otic development, only the dorsomedial half of the cup makes intimate contact with the hindbrain (Aa). As invagination proceeds, medial otic cells that at otic cup stage were in contact with the dorsal part of the hindbrain and were Wnt-responsive cells (blue dots in Aa), are now located in more ventral position (blue dots in $A b$ ) and receive signals from the ventral aspect of the neural tube. Hh signals from the notochord and floorplate (red arrows) are received in the ventral part of the otic cup, directly, or indirectly through a relay mechanism involving the mesenchyme and are essential for cochlear specification and SAG formation. Putative FGF signals (green arrows) downstream of $r 5$ - $r 6$ segmentation genes are received in dorsomedial otic tissue and are essential for vestibular fate. (B) In zebrafish, the otic vesicle receives dorsalising signals from the neural tube (presumably Wnt signals, blue arrows). Hh signals from the notochord and floorplate are received in the posteroventral otic vesicle (facing $r 5-r 6)(B b)$, where they specify posterior fate. In the anterior otocyst (facing r4) (Ba) FGF signaling is active and specifies anterior fate. Possibly as a consequence, Shh signal is antagonized (orange).

patterns of $\mathrm{Hh}$ target genes in these experimental contexts, a direct effect of $\mathrm{Hh}$ signaling on posterior otic cells is proposed (Hammond et al., 2003).

The role of canonical Wnt signaling from the dorsal neural tube has been studied in mouse (Riccomagno et al., 2005). Surprisingly, while Wnt-responsive cells are distributed along the dorsomedial otic cup and later confined to the dorsal aspect of the 
otic vesicle, both vestibular and cochlear structures are reduced in double Wnt1/Wnt3a mutants (Riccomagno et al., 2005). To explain these conflicting observations, the authors performed lineage studies using an inducible genetic marker of Wnt-responsive cells. They show that progenitors of the cochlea received Wnt signaling, demonstrating that these ventral cells originate from the dorsomedial part of the otic cup. This study underlines the contribution of cell migration and morphogenetic movements to otic patterning processes: otic cell groups originally located close to the dorsal neural tube will end up being ventral after otic invagination. Gain-of-function studies confirmed the role of canonical Wnt pathway in vestibular formation and showed a mutual repression between Wnt and Shh pathways in ear DV patterning. However, Wnt signals cannot be the only cues involved since ventral otic determinants are appropriately expressed in double mutants for Wnt1 and Wnt3a (Riccomagno et al., 2005). Other dorsal secreted cues, such as BMPs, could play a role in this process.

\section{Otic patterning in amniotes and zebrafish: similarity or specificity?}

Current data provide contrasting evidence regarding the role of hindbrain signals in otic axis specification in different vertebrates. Is this due to incomplete experimental data or to true differences in the mechanisms of ear patterning? There are arguments in favour of the second hypothesis: for instance, the main structure specified by Shh signaling in the mouse, the cochlea, does not have any counterpart in zebrafish. It could be argued, however, that the structures specified by $\mathrm{Hh}$ signaling in zebrafish and amniotes are functionally similar: the posterior (saccular) macula in zebrafish and the ventral cochlea in amniotes are both involved in hearing. Similarly, dorsal structures in amniotes and the anterior (utricular) macula in zebrafish have vestibular function. Therefore, similar patterning mechanisms could be used in different vertebrate species to specify similar functional parts of the inner ear.

Figure 6 summarizes the signals proposed to pattern the otocyst in fish and amniotes and the different structures specified by these signals. In amniotes, the available data show that the hindbrain is involved in DV patterning of the ear. In chicken, ablation of both the floor plate and notochord result in loss of ventral structures, while ablation of the neural tube results in loss of vestibular structures (Bok et al., 2005). On the other hand, rotation of the $r 4-r 7$ region of the hindbrain along the AP axis at a stage when the AP orientation of the otocyst was still plastic did not affect the establishment of the AP axis of the ear. This strongly suggests that, in this species, the rhombomeric identity is not an essential cue for ear AP patterning. However, it is interesting to note that this rotation does not change the position of the hindbrain FGF3 source relative to the otic vesicle. Together, these results suggest that hindbrain (and notochord) signals are mainly involved in DV patterning of the inner ear, consistent with functional analyses in mice. They also support the hypothesis that the spatial distribution of the signaling molecules along the AP axis of the hindbrain is not essential for proper patterning. This means that, if FGF signaling from r5-r6 has a role in ear patterning, its global level rather than its distribution may be important. Accordingly, the level of Fgf3gene expression in the caudal hindbrain is under the control of segmentation genes such as MafB and Hoxa1 (Figure 4). It cannot be totally excluded, however, that hindbrain signals also affect the early subdivision of neurogenic (anterior) versus non-neurogenic (posterior) domains. Indeed, an ongoing study (C. Vázquez-Echeverría and C. Pujades, in preparation) shows that kreisler mutants display an expansion of the otic neurogenic region as a result of changes in the early expression of otic patterning genes such as $L F n g$ and $L m \times 1$. Thus, in addition to the published DV and ML patterning defects, kreisler mutants display an early AP patterning defect, affecting mainly the neurogenic/non-neurogenic fate decision or other aspects of AP patterning of the ear, which may not have been carefully analyzed so far.

The situation is quite different in zebrafish: the study of the vhnf1 and $v a /$ mutants has clearly shown an involvement of hindbrain cues in AP patterning. FGF has been proposed as the main signal involved in otic AP patterning downstream of these hindbrain segmentation genes, but Hh signals also play a role in this process. An intriguing question is how a ventral signal such as $\mathrm{Hh}$, which shows an even distribution along the AP axis, can specify AP patterning of the otic vesicle. Several hypotheses can be made. First, the posterior part of the ear may receive more signal than its anterior part. This could be achieved by tilting the early axes of the otic vesicles relative to that of the neural tube. Second, the Shh signal may interact with AP restricted cues. FGFs signals from the hindbrain are good candidates to locally restrict the differential response to $\mathrm{Hh}$ signaling of the ventral otic cells. The control of FGF and Hh production is independent: the production of the FGF signal is not affected in $H$ h mutants (Hammond et al., 2003) and hhexpression in hindbrain segmentation mutants is not affected (our unpublished data). Therefore, the interaction may operate at the level of receiving cells in the ear (Riccomagno et al., 2002). More recently, DV patterning has also been shown to be affected in vhnfland va/mutants. However, the signaling pathways involved in this DV patterning process have not been identified so far. Wnt 1 and $W n t 3 a$ expression is reduced in $r 5$ and $r 6$ in vhnf1 mutants, suggesting that Wnt signals may be involved in some aspects of zebrafish ear DV patterning (Lecaudey et al., 2007).

\section{Future directions}

In this review we have discussed the current view on the role of hindbrain signals in axial specification of the inner ear. Essential information has been brought by the analysis of mutants of hindbrain segmentation genes, as well as by the functional analysis of some signaling pathways. As we mentioned, the available information is still fragmentary. In particular, more complete fate maps and lineage studies must be performed in different vertebrate species and at different stages of development. It would also be helpful to know with better precision when the different structures, sensory and non-sensory, of the inner ear are specified in each species.

Hindbrain signals may have additional functions in otic patterning. For instance, it is intriguing that both in zebrafish and amniotes, sensory markers appear at anterior and posterior extremities of the otic vesicle. In zebrafish valand vhnf1 mutants, where $r 5$ is absent, tether cells of the maculae are specified at ectopic positions along the otic AP axis, correlating with the extent 
of krox20 reduction (Lecaudey et al., 2007). These data suggest that a signal from $r 5$ restricts sensory cell specification. To test this hypothesis, it would be useful to analyze the inner ear of mice and fish with a loss of function of krox20, a gene involved in the formation of $r 3$ and $r 5$.

To gain a better understanding of the issue, the involvement of different signaling pathways has to be studied in greater detail. In that respect, the potential function of BMP signals is an interesting question to address. Indeed, BMP pathway genes are expressed in the dorsal neural tube and surrounding dorsal ectoderm and BMP antagonists display a rhombomere-specific pattern (Seitanidou et al., 1997).

Finally, signals from surrounding tissues may be involved in other aspects of ear patterning. As an example, none of the hindbrain mutants examined so far display changes in AP position of the SAG, suggesting that it is under the tight control of hindbrain-independent signals. Another signaling pathway involved in ear patterning is the retinoid pathway. Both in mice and humans, variations in retinoid levels have profound effects on ear formation. Furthermore, the defects seen in ear formation in mouse Hoxa1 mutants are rescued by treatment with non teratogenic doses of RA (Pasqualetti et al., 2001). At placode and early otocyst stages, RA is synthesized in the somitic mesoderm and may act, not only by controlling segmental gene expression in the hindbrain and, in consequence, FGF3 signaling, but also directly on the otocyst (for review Romand, 2003; Romand et al., 2006). The identification of other signals and their integration with hindbrain-derived signaling pathways will lead to a more complete picture of the mechanisms of inner ear patterning.

\section{Acknowledgements}

We are grateful to Dora Sapede, François Giudicelli and Christine Vesque for critical reading of the manuscript and helpful suggestions and to Sophie Gournet for artwork. This work is supported by grants BFU200605604 from MEC, Spain to C.P.; and ARC, FRM, CNRS and Université Pierre et Marie Curie (Paris 6) to S.S.M. The authors are supported by a joint PICS collaboration programme (CNRS-Generalitat de Catalunya).

\section{References}

ABELLO, G., KHATRI, S., GIRALDEZ, F. and ALSINA, B. (2007). Early regionalization of the otic placode and its regulation by the notch signaling pathway. Mech. Dev., Apr. 20; [Epub ahead of print].

ADAMSKA, M., LEGER, S., BRAND, M., HADRYS, T., BRAUN, T. and BOBER, E. (2000). Inner ear and lateral line expression of a zebrafish $N k \times 5-1$ gene and its downregulation in the ears of FGF8 mutant, ace. Mech. Dev. 1-2, 161-165.

AKIMENKO, M.A., EKKER, M., WEGNER, J., LIN, W. and WESTERFIELD, M. (1994). Combinatorial expression of three zebrafish genes related to distal-less: part of a homeobox gene code for the head. J. Neurosci. 6, 3475-3486.

ALSINA, B., ABELLO, G., ULLOA, E., HENRIQUE, D., PUJADES, C. and GIRALDEZ, F. (2004). FGF signaling is required for determination of otic neuroblasts in the chick embryo. Dev. Biol. 1, 119-134.

ALVAREZ, Y., ALONSO, M.T., VENDRELL, V., ZELARAYAN, L.C., CHAMERO, P., THEIL, T., BOSL, M.R., KATO, S., MACONOCHIE, M., RIETHMACHER, D. and SCHIMMANG, T. (2003). Requirements for FGF3 and FGF10 during inner ear formation. Development 25, 6329-6338.

ANDERMANN, P., UNGOS, J. and RAIBLE, D.W. (2002). Neurogenin1 defines zebrafish cranial sensory ganglia precursors. Dev. Biol. 1, 45-58.

ARAGON, F., VAZQUEZ-ECHEVERRIA, C., ULLOA, E., REBER, M., CEREGHINI, S., ALSINA, B., GIRALDEZ, F. and PUJADES, C. (2005). vHnf1 regulates specification of caudal rhombomere identity in the chick hindbrain. Dev. Dyn. 3, 567-576.
BARALD, K.F. and KELLEY, M.W. (2004). From placode to polarization: new tunes in inner ear development. Development 17, 4119-4130.

BAUER, M.P. and GOETZ, F.W. (1998). Zebrafish mutagenesis: A screen for reproductive mutants. Biol. Reprod. 104-104.

BOK, J., BRONNER-FRASER, M. and WU, D.K. (2005). Role of the hindbrain in dorsoventral but not anteroposterior axial specification of the inner ear. Deve/opment 9, 2115-2124.

BOK, J., DOLSON, D.K., HILL, P., RUTHER, U., EPSTEIN, D.J. and WU, D.K. (2007). Opposing gradients of Gli repressor and activators mediate Shh signaling along the dorsoventral axis of the inner ear. Development 134, 17131722.

BRICAUD, O. and COLLAZO, A. (2006). The transcription factor six 1 inhibits neuronal and promotes hair cell fate in the developing zebrafish (Danio rerio) inner ear. J. Neurosci. 41, 10438-10451.

BRIGANDE, J.V., ITEN, L.E. and FEKETE, D.M. (2000a). A fate map of chick otic cup closure reveals lineage boundaries in the dorsal otocyst. Dev. Biol. 2, 256270.

BRIGANDE, J.V., KIERNAN, A.E., GAO, X., ITEN, L.E. and FEKETE, D.M. (2000b). Molecular genetics of pattern formation in the inner ear: do compartment boundaries play a role? Proc. Natt. Acad. Sci. USA. 22, 11700-11706.

BURTON, Q., COLE, L.K., MULHEISEN, M., CHANG, W. and WU, D.K. (2004). The role of Pax2 in mouse inner ear development. Dev. Biol. 1, 161-175.

CANTOS, R., COLE, L.K., ACAMPORA, D., SIMEONE, A. and WU, D.K. (2000). Patterning of the mammalian cochlea. Proc. Natt. Acad. Sci. USA. 22, 1170711713.

CHAMBERS, D., MEDHURST, A.D., WALSH, F.S., PRICE, J. and MASON, I. (2000). Differential display of genes expressed at the midbrain - hindbrain junction identifies sprouty2. an FGF8-inducible member of a family of intracellular FGF antagonists. Mol. Cell. Neurosci. 1, 22-35.

CHOO, D., WARD, J., REECE, A., DOU, H., LIN, Z. and GREINWALD, J. (2006). Molecular mechanisms underlying inner ear patterning defects in kreisler mutants. Dev. Biol. 2, 308-317.

COLE' L.K., LE ROUX' I., NUNES, F. LAUFER, E., LEWIS, J. and WU, D.K. (2000) Sensory organ generation in the chicken inner ear: Contributions of Bone morphogenetic protein 4, Serrate1 and Lunatic fringe. J. Comp. Neurol. 424, 509-520

DOLLE, P., LUFKIN, T., KRUMLAUF, R., MARK, M., DUBOULE, D. and-CHAMBON, P. (1993). Local alterations of Krox-20and Hoxgene expression in the hindbrain suggest lack of rhombomeres 4 and 5 in homozygote null Hoxa-1 (Hox-1.6) mutant embryos. Proc. Natl. Acad. Sci. USA. 16, 7666-7670.

EICHMANN, A., GRAPIN-BOTTON, A., KELLY, L., GRAF, T., LE DOUARIN, N.M. and SIEWEKE, M. (1997). The expression pattern of the mafB/krgene in birds and mice reveals that the kreis/erphenotype does not represent a null mutant. Mech. Dev. 1-2, 111-122.

FARIÑAS, I., JONES, K.R., TESSAROLLO, L., VIGERS, A.J., HUANG, E., KIRSTEIN, M., DE CAPRONA, D.C., COPPOLA, V., BACKUS, C., REICHARDT, L.F. and FRITZSCH, B. (2001) Spatial shaping of cochlear innervation by temporally regulated neurotrophin expression. J Neurosci21, 6170-6180

FEKETE, D.M. (1999). Development of the vertebrate ear: insights from knockouts and mutants. Trends Neurosci. 6, 263-269.

FEKETE, D.M. and WU, D.K. (2002). Revisiting cell fate specification in the inner ear. Curr. Opin. Neurobiol. 1, 35-42.

GIRALDEZ, F. (1998). Regionalized organizing activity of the neural tube revealed by the regulation of $I m \times 1$ in the otic vesicle. Dev. Biol. 1, 189-200.

GIUDICELLI, F., GILARDI-HEBENSTREIT, P., MECHTA-GRIGORIOU, F., POQUET, C. and CHARNAY, P. (2003). Novel activities of Mafbunderlie its dual role in hindbrain segmentation and regional specification. Dev. Biol. 1, 150-162.

GLOVER, J.C., RENAUD, J.S. and RIJLI, F.M. (2006). Retinoic acid and hindbrain patterning. J. Neurobiol. 7, 705-725.

GOULD, A., ITASAKI, N. and KRUMLAUF, R. (1998). Initiation of rhombomeric Hoxb4expression requires induction by somites and a retinoid pathway. Neuron 1, 39-51.

HADDON, C. and LEWIS, J. (1996). Early ear development in the embryo of the zebrafish, Danio rerio. J. Comp. Neurol. 1, 113-128.

HAMMOND, K.L., HILL, R.E., WHITFIELD, T.T. and CURRIE, P.D. (2002). Isola- 
tion of three zebrafish dachshundhomologues and their expression in sensory organs, the central nervous system and pectoral fin buds. Mech. Dev. 1-2, 183189.

HAMMOND, K.L., LOYNES, H.E., FOLARIN, A.A., SMITH, J. and WHITFIELD, T.T. (2003). Hedgehog signalling is required for correct anteroposterior patterning of the zebrafish otic vesicle. Development 7, 1403-1417.

HANS, S., LIU, D. and WESTERFIELD, M. (2004). Pax8 and Pax2a function synergistically in otic specification, downstream of the Foxi1 and $D / x 3 b$ transcription factors. Development 20, 5091-5102.

HELMBACHER, F., PUJADES, C., DESMARQUET,C., FRAIN, M., RIJLI, F., CHAMBON, P. and CHARNAY, P. (1998) Hoxa-1 and Krox-20synergize in the patterning of rhombomere 3. Development 125, 4739-4748.

HERNANDEZ, R.E., RIKHOF, H.A., BACHMANN, R. and MOENS, C.B. (2004). vhnf1 integrates global RA patterning and local FGF signals to direct posterior hindbrain development in zebrafish. Development 18, 4511-4520.

HERNANDEZ, R.E., PUTZKE, A.P., MYERS, J.P., MARGARETHA, L. and MOENS, C.B. (2007). Cyp26 enzymes generate the retinoic acid response pattern necessary for hindbrain development. Development 1, 177-187.

JESSELL, T.M. (2000). Neuronal specification in the spinal cord: inductive signals and transcriptional codes. Nat. Rev. Genet. 1, 20-29.

KELLEY, M.W. (2006). Regulation of cell fate in the sensory epithelia of the inner ear. Nat. Rev. Neurosci. 11, 837-849.

KIERNAN, A.E., ERVEN, A., VOEGELING, S., PETERS, J., NOLAN, P., HUNTER, J., BACON, Y., STEEL, K.P., BROWN, S.D.M. and GUENET, J.L. (2002). ENU mutagenesis reveals a highly mutable locus on mouse Chromosome 4 that affects ear morphogenesis. Mammalian Genome 3, 142-148.

KIL, S.H. and COLLAZO, A. (2001). Origins of inner ear sensory organs revealed by fate map and time-lapse analyses. Dev. Biol. 2, 365-379.

KIL, S.H. and COLLAZO, A. (2002). A review of inner ear fate maps and cell lineage studies. J. Neurobiol. 2, 129-142.

KOZLOWSKI, D. J., MURAKAMI, T., HO, R.K. and WEINBERG, E.S. (1997). Regional cell movement and tissue patterning in the zebrafish embryo revealed by fate mapping with caged fluorescein. Biochem. Cell Biol., 75, 551-562.

KOZLOWSKI, D.J., WHITFIELD, T.T., HUKRIEDE, N.A., LAM, W.K. and WEINBERG, E.S. (2005). The zebrafish dog-eared mutation disrupts eya1, a gene required for cell survival and differentiation in the inner ear and lateral line. Dev. Biol. 1, 27-41.

KRAUSS, S., JOHANSEN, T., KORZH, V., MOENS, U., ERICSON, J.U. and FJOSE, A. (1991). Zebrafish Pax2aPaired Box-Containing Gene Expressed in the Neural-Tube. EMBO J. 12, 3609-3619.

KWAK, S.J., PHILLIPS, B.T., HECK, R. and RILEY, B.B. (2002). An expanded domain of fgf3expression in the hindbrain of zebrafish valentinomutants results in mis-patterning of the otic vesicle. Development 22, 5279-5287.

KWAK, S.J., VEMARAJU, S., MOORMAN, S.J., ZEDDIES, D., POPPER, A.N. and RILEY, B.B. (2006). Zebrafish pax5 regulates development of the utricular macula and vestibular function. Dev. Dyn. 11, 3026-3038.

LADHER, R. K., WRIGHT, T., J., MOON, A., M., MANSOUR, S. L. and SCHOENWOLF, G. C. (2005). FGF8 initiates inner ear indication in chick and mouse. Genes and Dev. 19, 603-613.

LANG, H. and FEKETE, D.M. (2001). Lineage analysis in the chicken inner ear shows differences in clonal dispersion for epithelial, neuronal and mesenchymal cells. Dev. Biol. 1, 120-137.

LECAUDEY, V., ULLOA, E., ANSELME, I., STEDMAN, A., SCHNEIDERMAUNOURY, S. and PUJADES, C. (2007). Role of the hindbrain in patterning the otic vesicle: a study of the zebrafish vhnf1 mutant. Dev. Biol. 1,134-43

LEE, K.J. and JESSELL, T.M. (1999). The specification of dorsal cell fates in the vertebrate central nervous system. Annu. Rev. Neurosci. 261-294.

LEGER, S. and BRAND, M. (2002). Fgf8 and Fgf3 are required for zebrafish ear placode induction, maintenance and inner ear patterning. Mech. Dev. 1, 91-108.

LIN, Z., CANTOS, R., PATENTE, M. and WU, D.K. (2005). Gbx2 is required for the morphogenesis of the mouse inner ear: a downstream candidate of hindbrain signaling. Development 10, 2309-2318.

LIU, D., CHU, H., MAVES, L., YAN, Y.L., MORCOS, P.A., POSTLETHWAIT, J.H. and WESTERFIELD, M. (2003). Fgf3 and Fgf8 dependent and independent transcription factors are required for otic placode specification. Development
$10,2213-2224$.

MA, Q., CHEN, Z., DEL BARCO BARRANTES, I., DE LA POMPA, J.L. and ANDERSON, D.J. (1998). neurogenin1 is essential for the determination of neuronal precursors for proximal cranial sensory ganglia. Neuron 20, 469-482

MAHMOOD, R., MASON, I.J. and MORRISS-KAY, G.M. (1996). Expression of Fgf3 in relation to hindbrain segmentation, otic pit position and pharyngeal arch morphology in normal and retinoic acid-exposed mouse embryos. Anat. Embryol. (Berl) 1, 13-22.

MARIN, F. and CHARNAY, P. (2000). Hindbrain patterning: FGFs regulate Krox20 and $m a f B / k$ rexpression in the otic/preotic region. Development22, 4925-4935.

MAROON, H., WALSHE, J., MAHMOOD, R., KIEFER, P., DICKSON, C. and MASON, I. (2002). Fgf3 and Fgf8are required together for formation of the otic placode and vesicle. Development 9, 2099-2108.

MARSHALL, H., STUDER, M., POPPERL, H., APARICIO, S., KUROIWA, A. BRENNER, S. and-KRUMLAUF, R. (1994). A conserved retinoic acid response element required for early expression of the homeobox gene Hoxb-1. Nature 6490, 567-571.

MAVES, L., JACKMAN, W. and KIMMEL, C.B. (2002). FGF3 and FGF8 mediate a rhombomere 4 signaling activity in the zebrafish hindbrain. Development 16 , 3825-3837.

MCKAY, I.J., MUCHAMORE, I., KRUMLAUF, R., MADEN, M., LUMSDEN, A. and LEWIS, J. (1994). The kreis/er mouse: a hindbrain segmentation mutant that lacks two rhombomeres. Development 8, 2199-2211.

MCKAY, I.J., LEWIS, J. and LUMSDEN, A. (1996). The role of FGF-3 in early inner ear development: an analysis in normal and kreis/ermutant mice. Dev. Biol. 2 , 370-378.

MERLO, G.R., PALEARI, L., MANTERO, S., ZEREGA, B., ADAMSKA, M., RINKWITZ, S., BOBER, E. and LEVI, G. (2002). The DIX5 homeobox gene is essential for vestibular morphogenesis in the mouse embryo through a BMP4mediated pathway. Dev. Biol. 1, 157-169.

MILLIMAKI, B.B., SWEET, E.M., DHASON, M.S. and RILEY, B.B. (2007). Zebrafish atoh1genes: classic proneural activity in the inner ear and regulation by Fgf and Notch. Development2, 295-305.

MOENS, C.B., CORDES, S.P., GIORGIANNI, M.W., BARSH, G.S. and KIMMEL, C.B. (1998). Equivalence in the genetic control of hindbrain segmentation in fish and mouse. Development 3, 381-391.

MORSLI, H., TUORTO, F., CHOO, D., POSTIGLIONE, M.P., SIMEONE, A. and WU, D.K. (1999). Otx 1 and Otx2activities are required for the normal development of the mouse inner ear. Development 11, 2335-2343.

MOWBRAY, C., HAMMERSCHMIDT, M. and WHITFIELD, T.T. (2001). Expression of BMP signalling pathway members in the developing zebrafish inner ear and lateral line. Mech. Dev. 1-2, 179-184.

PASQUALETTI, M., NEUN, R., DAVENNE, M. and RIJLI, F.M. (2001). Retinoic acid rescues inner ear defects in Hoxa1 deficient mice. Nat. Genet. 1, 34-39.

PAULEY, S., WRIGHT, T.J., PIRVOLA, U., ORNITZ, D., BEISEL, K. and FRITZSCH, B. (2003). Expression and function of FGF10 in mammalian inner ear development. Dev Dyn 227, 203-215

PFEFFER, P.L., GERSTER, T., LUN, K., BRAND, M. and BUSSLINGER, M. (1998). Characterization of three novel members of the zebrafish Pax $2 / 5 / 8$ family: dependency of Pax5and Pax8 expression on the Pax2.1 (noi)function. Development 16, 3063-3074.

PHILLIPS, B.T., BOLDING, K. and RILEY, B.B. (2001). Zebrafish fgf3 and fgf8 encode redundant functions required for otic placode induction. Dev. Biol. 2, 351-365.

PHILLIPS, B.T., STORCH, E.M., LEKVEN, A.C. and RILEY, B.B. (2004). A direct role for Fgf but not Wnt in otic placode induction. Development 4, 923-931.

PRINCE, V.E., MOENS, C.B., KIMMEL, C.B. and HO, R.K. (1998). Zebrafish hox genes: expression in the hindbrain region of wild-type and mutants of the segmentation gene, valentino. Development3, 393-406.

PUJADES, C., KAMAID, A., ALSINA, B. and GIRALDEZ, F. (2006). BMP-signaling regulates the generation of hair-cells. Dev. Biol. 1, 55-67.

RAFT, S., NOWOTSCHIN, S., LIAO, J. and MORROW, B.E. (2004). Suppression of neural fate and control of inner ear morphogenesis by Tbx1. Development 8 , 1801-1812.

RAIBLE, F. and BRAND, M. (2001). Tight transcriptional control of the ETS domain 
factors Erm and Pea3 by Fgf signaling during early zebrafish development. Mech. Dev. 1-2, 105-117.

REIFERS, F., BOHLI, H., WALSH, E.C., CROSSLEY, P.H., STAINIER, D.Y. and BRAND, M. (1998). Fgf8 is mutated in zebrafish acerebellar (ace) mutants and is required for maintenance of midbrain-hindbrain boundary development and somitogenesis. Development 13, 2381-2395.

REPRESA, J., LEON, Y., MINER, C. and GIRALDEZ, F. (1991). The int-2 protooncogene is responsible for induction of the inner ear. Nature 6344, 561-563.

RICCOMAGNO, M.M., MARTINU, L., MULHEISEN, M., WU, D.K. and EPSTEIN, D.J. (2002). Specification of the mammalian cochlea is dependent on Sonic hedgehog. Genes Dev. 18, 2365-2378.

RICCOMAGNO, M.M., TAKADA, S. and EPSTEIN, D.J. (2005). Wnt-dependent regulation of inner ear morphogenesis is balanced by the opposing and supporting roles of Shh. Genes Dev. 13, 1612-1623.

RILEY, B.B. and PHILLIPS, B.T. (2003). Ringing in the new ear: resolution of cell interactions in otic development. Dev. Biol. 2, 289-312.

ROMAND, R. (2003). The roles of retinoic acid during inner ear development. Curr. Top. Dev. Biol. 261-291.

ROMAND, R., DOLLE, P. and HASHINO, E. (2006). Retinoid signaling in inner ear development. J. Neurobiol. 7, 687-704.

SADL, V.S., SING, A., MAR, L., JIN, F. and CORDES, S.P. (2003). Analysis of hindbrain patterning defects caused by the kreisler(enu) mutation reveals multiple roles of Kreisler in hindbrain segmentation. Dev. Dyn. 1, 134-142.

SAHLY, I., ANDERMANN, P. and PETIT, C. (1999). The zebrafish eya1 gene and its expression pattern during embryogenesis. Dev. Genes Evol. 7, 399-410.

SAMAD, O.A., GEISEN, M.J., CARONIA, G., VARLET, I., ZAPPAVIGNA, V., ERICSON, J., GORIDIS, C. and RIJLI, F.M. (2004). Integration of anteroposterior and dorsoventral regulation of $P$ hox $2 b$ transcription in cranial motoneuron progenitors by homeodomain proteins. Development 16, 4071-4083.

SATOH, T. and FEKETE, D.M. (2005). Clonal analysis of the relationships between mechanosensory cells and the neurons that innervate them in the chicken ear. Development 7, 1687-1697.

SCHNEIDER-MAUNOURY, S., TOPILKO, P., SEITANDOU, T., LEVI, G., COHENTANNOUDJI, M., POURNIN, S., BABINET, C. and CHARNAY, P. (1993). Disruption of Krox-20 results in alteration of rhombomeres 3 and 5 in the developing hindbrain. Cel/6, 1199-1214.

SCHNEIDER-MAUNOURY, S., SEITANIDOU, T., CHARNAY, P. and LUMSDEN, A. (1997). Segmental and neuronal architecture of the hindbrain of Krox-20 mouse mutants. Development 6, 1215-1226.

SCHNEIDER-MAUNOURY, S., GILARDI-HEBENSTREIT, P. and CHARNAY, P. (1998). How to build a vertebrate hindbrain. Lessons from genetics. C. R. Acad. Sci. I/I10, 819-834.

SEITANIDOU, T., SCHNEIDER-MAUNOURY, S., DESMARQUET, C. and
WILKINSON, D., CHARNAY, P. (1997). Krox-20is a key regulator of rhombomerespecific gene expression in the developing hindbrain. Mech. Dev. 65, 31-35.

SIRBU, I.O., GRESH, L., BARRA, J. and DUESTER, G. (2005). Shifting boundaries of retinoic acid activity control hindbrain segmental gene expression. Development 11, 2611-2622.

STREIT, A. (2002). Extensive cell movements accompany formation of the otic placode. Dev. Biol. 2, 237-254.

SUN, Z. and HOPKINS, N. (2001). vhnf1, the MODY5 and familial GCKD-associated gene, regulates regional specification of the zebrafish gut, pronephros and hindbrain. Genes Dev. 23, 3217-3229.

TORRES, M., GOMEZ-PARDO, E. and GRUSS, P. (1996). Pax2 contributes to inner ear patterning and optic nerve trajectory. Development 11, 3381-3391.

TRAINOR, P.A. and KRUMLAUF, R. (2001). Hox genes, neural crest cells and branchial arch patterning. Curr. Opin. Cell Biol. 6, 698-705.

VENDRELL, V., CARNICERO, E., GIRALDEZ, F., ALONSO, M.T. and SCHIMMANG, T. (2000). Induction of inner ear fate by FGF3. Development 10, 2011-2019.

VOICULESCU, O., TAILLEBOURG, E., PUJADES, C., KRESS, C., BUART, S., CHARNAY, P. and SCHNEIDER-MAUNOURY, S. (2001). Hindbrain patterning: Krox20 couples segmentation and specification of regional identity. Deve/opment 24, 4967-4978.

WALSHE, J., MAROON, H., MCGONNELL, I.M., DICKSON, C. and MASON, I. (2002). Establishment of hindbrain segmental identity requires signaling by FGF3 and FGF8. Curr. Biol. 13, 1117-1123.

WANG, W., VAN DE WATER, T. and LUFKIN, T. (1998). Inner ear and maternal reproductive defects in mice lacking the Hmx3 homeobox gene. Development 4, 621-634.

WANG, W., CHAN, E.K., BARON, S., VAN DE WATER, T. and LUFKIN, T. (2001). $H m \times 2$ homeobox gene control of murine vestibular morphogenesis. Development 24, 5017-5029.

WIELLETTE, E.L. and SIVE, H. (2003). vhnf1 and Fgfsignals synergize to specify rhombomere identity in the zebrafish hindbrain. Development 16, 3821-3829.

WRIGHT, T.J. and MANSOUR, S.L. (2003). Fgf3and Fgf10are required for mouse otic placode induction. Development 15, 3379-3390.

WU, D.K., NUNES, F.D. and CHOO, D. (1998). Axial specification for sensory organs versus non-sensory structures of the chicken inner ear. Development 1 , 11-20.

XU, H., VIOLA, A., ZHANG, Z., GERKEN, C.P., LINDSAY-ILLINGWORTH, E.A. and BALDINI, A. (2007). TbX1 regulates population, proliferation and cell fate determination of otic epithelial cells. Dev. Biol. 2, 670-682.

Published Online: 27th August 2007 


\section{Related, previously published Int. J. Dev. Biol. articles}

See our Special Issue Ear Development edited by Fernando Giraldez and Bernd Fritzsch at: http://www.ijdb.ehu.es/web/contents.php?vol=51\&issue=6-7

The puzzle of Hox genes.

A E Carrasco and S L López

Int. J. Dev. Biol. (1994) 38: 557-564

Genetic control of dorsoventral patterning and neuroblast specification in the Drosophila Central Nervous System Guoyan Zhao, Scott R. Wheeler and James B. Skeath

Int. J. Dev. Biol. (2007) 51: 107-115

Where do we stand now? - mouse early embryo patterning meeting in Freiburg, Germany (2005)

Takashi Hiiragi, Vernadeth B. Alarcon, Toshihiko Fujimori, Sophie Louvet-Vallée, Marek Maleszewski, Yusuke Marikawa, Bernard Maro and Davor Solter

Int. J. Dev. Biol. (2006) 50: 581-588

Principles of branch formation and branch patterning in Hydrozoa

Stefan Berking

Int. J. Dev. Biol. (2006) 50: 123-134

Head-tail patterning of the vertebrate embryo: one, two or many unresolved problems?

Claudio D. Stern, Jeroen Charité, Jacqueline Deschamps, Denis Duboule, Anthony J. Durston, Marie Kmita, Jean-François Nicolas, Isabel Palmeirim, Jim C. Smith and Lewis Wolpert

Int. J. Dev. Biol. (2006) 50: 3-15

Antero-posterior patterning of the vertebrate digestive tract: $\mathbf{4 0}$ years after Nicole Le Douarin's PhD thesis Anne Grapin-Botton

Int. J. Dev. Biol. (2005) 49: 335-347

Single-cell transcriptional profiles and spatial patterning of the mammalian olfactory epithelium Ian Tietjen, Jason Rihel and Catherine G. Dulac

Int. J. Dev. Biol. (2005) 49: 201-207 